\title{
Functional $\gamma \delta$ T-lymphocyte Defect Associated with Human Immunodeficiency Virus Infections
}

\author{
Marianne Wallace, ${ }^{1}$ Alexander M. Scharko, ${ }^{1,2}$ C. David Pauza, ${ }^{2,4}$ \\ Paul Fisch, ${ }^{3,5}$ Koichi Imaoka, ${ }^{6}$ Shigetada Kawabata, ${ }^{6}$ \\ Kohtaro Fujihashi, ${ }^{6}$ Hiroshi Kiyono, $^{6}$ Yoshimasa Tanaka, $^{7}$ \\ Barry R. Bloom, ${ }^{7}$ and Miroslav Malkovsky ${ }^{1,3,4}$
}

Departments of Medical Microbiology and Immunology, ${ }^{1}$ Pathology

and Laboratory Medicine, ${ }^{2}$ and Human Oncology, ${ }^{3}$ University of

Wisconsin Medical School, Madison, Wisconsin, U.S.A.

${ }^{4}$ Immunology and Virology Research Group, Wisconsin Regional

Primate Research Center, Madison, Wisconsin, U.S.A.

${ }^{5}$ Department of Medicine I, University Hospital Freiburg, Freiburg, Germany

${ }^{6}$ Department of Oral Biology, University of Alabama at Birmingham

Medical Center, Birmingham, Alabama, U.S.A.

${ }^{7}$ Howard Hughes Medical Institute and Departments of Microbiology and

Immunology, Albert Einstein College of Medicine, Bronx, New York, U.S.A.

\begin{abstract}
Background: Antiviral cellular immune responses may influence immunological homeostasis in HIV-infected persons. Recent data indicate that $\mathrm{V} \gamma 9 / \mathrm{V} \delta 2 \mathrm{~T}$ lymphocytes display potent cytotoxic activities against human cells infected with certain viruses including HIV. Understanding the role of $\gamma \delta \mathrm{T}$ cells in the course of HIV infection may be helpful for designing novel treatment strategies for HIV-associated disorders.

Materials and Methods: The constitutive recognition of Daudi cells and monoethyl pyrophosphate (Etpp) by peripheral blood $\mathrm{V} \gamma 9 / \mathrm{V} \delta 2 \mathrm{~T}$ cells was assessed using a proliferation assay. The cytotoxicity of Daudi-stimulated lymphocyte populations was measured by chromium release assays. The HIV infectivity for $\gamma \delta \mathrm{T}$ cell clones was determined by measuring the levels of HIV p24 in cell supernatants. The effect of in vitro HIV-infection on cytokine mRNA production by $\gamma \delta \mathrm{T}$ cell clones was assessed by PCR.
\end{abstract}

Results: The constitutive proliferative responses of peripheral blood $\mathrm{V} \gamma 9 / \mathrm{V} \delta 2 \mathrm{~T}$ cells and the lytic functions of Daudi-expanded lymphoid cells from HIV+ persons were substantially diminished in comparison with those of HIV-seronegative persons. These alterations were present in asymptomatic HIV+ persons prior to substantial $\alpha \beta \mathrm{CD}^{+}{ }^{+} \mathrm{T}$ cell loss. Productive HIV infection of $\gamma \delta \mathrm{T}$ cells in vitro had no measurable effect either on their proliferative response to Daudi stimuli or on the expression of cytokine mRNAs for IFN- $\gamma, \mathrm{IL}-2, \mathrm{IL}-4, \mathrm{IL}-5, \mathrm{IL}-6$, IL-10, and IL-13.

Conclusions: The constitutive responsiveness of $\mathrm{V} \gamma 9$ / V $\delta 2 \mathrm{~T}$ lymphocytes to Daudi and Etpp is severely altered in HIV+ persons. HIV infection of $\gamma \delta$ T cells in vitro does not substantially change their cytokine expression or antigenic response.

\section{INTRODUCTION}

In the second decade of the acquired immunodeficiency syndrome (AIDS) epidemic, our understanding of the pathogenesis of human im-

Address correspondence and reprint requests to: Miroslav Malkovsky, 1300 University Ave., Department of Medical Microbiology and Immunology, University of Wisconsin Medical School, Madison, WI 53706, U.S.A. munodeficiency virus (HIV) infection has improved dramatically (1). The primary infection has been analyzed in detail (2-4), rates of HIV replication in vivo have been extensively studied (5-7), and eventual clinical manifestations of the infection are well recognized $(8,9)$. Although the relative importance of individual elements of the immune response contributing to anti-HIV immunosurveillance is unclear, the critical role of 
cellular immune responses has not been disputed (1). In addition to $\alpha \beta \mathrm{T}$ lymphocytes, potent antiviral immune responses may be mediated by $\gamma \delta \mathrm{T}$ lymphocytes $(10)$. In putatively healthy, HIV-uninfected individuals, $\gamma \delta \mathrm{T}$ cells typically constitute 1 to $10 \%$ of peripheral blood lymphocytes and are found with comparable or greater numbers in various lymphoid tissues (11-13). Remarkably, 60 to $90 \%$ of human peripheral blood $\gamma \delta \mathrm{T}$ lymphocytes in adults express a unique combination of $\mathrm{V} \gamma 9$ and $\mathrm{V} \delta 2 \mathrm{~T}$ cell receptor (TCR) chains (14). $\gamma \delta \mathrm{T}$ cell reactivity against microorganisms, infected or malignant cells (reviewed in 10, 15, and 16), and the propensity of $\gamma \delta$ T cells to recognize nonpeptide antigens, such as isopentenyl pyrophosphate produced by mycobacteria (17), are compatible with the hypothesis that $\gamma \delta \mathrm{T}$ cells provide host immunosurveillance, complementing that provided by $\alpha \beta \mathrm{T}$ cells. The fact that nonpeptide antigens recognized by $\gamma \delta \mathrm{T}$ cells are important intermediates in many metabolic pathways in both eukaryotes and prokaryotes and that their presentation does not require antigen presentation or processing (accelerating the recognition process) strongly suggest that $\gamma \delta \mathrm{T}$ lymphocytes may have unique physiological functions in response to infections $(16,17)$.

Our previous study has shown that approximately $40 \%$ of $\mathrm{V} \gamma 9 / \mathrm{V} \delta 2 \mathrm{~T}$ cell clones isolated from HIV-seronegative donors lyse HIV-infected $\mathrm{T}$ cells (18). $\gamma \delta \mathrm{T}$ cell-mediated cytotoxicity against HIV-infected cells resembles that against simian immunodeficiency virus (SIV)-, herpes simplex virus (HSV)-, vaccinia virus-, or human herpesvirus-6 (HHV-6)-infected cells, as it is similarly independent of prior exposure to viral antigens or virally infected cells $(18-23)$. Although alterations of $\gamma \delta \mathrm{T}$ cell numbers and subset representation in peripheral blood of HIV-seropositive donors have been studied by several groups (24-28), a functional assessment of $\gamma \delta \mathrm{T}$ cells in HIV-infected individuals has not been reported. To initiate such an investigation, we have compared the TCR-mediated responsiveness of $\mathrm{V} \gamma 9 / \mathrm{V} \delta 2 \mathrm{~T}$ cells from HIV-seropositive and seronegative persons towards the Daudi Burkitt's lymphoma or Etpp, both of which stimulate $\mathrm{V} \gamma 9 / \mathrm{V} \delta 2 \mathrm{~T}$ cell proliferation $(17,29-31)$, and analyzed the in vitro effect of HIV infection on cytokine mRNA expression by $\gamma \delta \mathrm{T}$ cells and their proliferation in response to Daudi cells.

\section{MATERIALS AND METHODS Blood Donors}

The Centers for Disease Control (CDC) stage of HIV infection in seven HIV-seropositive (SP) persons was as follows: stage Al, blood donor SP1; stage A2, donor SP2; stage B2, donors SP3, SP5, and SP6; stage C3, donors SP4 and SP7. Five HIV-seronegative (SN) persons included four putatively healthy blood donors (SNI-4) and a donor with idiopathic low CD4 count (SN5). For $\mathrm{HIV}+$ donors, the absolute $\mathrm{CD} 4^{+} \mathrm{T}$ cell counts in $1 \mu \mathrm{l}$ of blood were as follows: SP1, 409; SP2, 374; SP3, 330; SP4, 22; SP5, 224; SP6, 409; SP7, 110. Additional clinical and laboratory details concerning some of the HIV+ donors have been reported elsewhere (32).

\section{Peripheral Blood Mononuclear Cell Isolation}

Peripheral blood mononuclear cells (PBMC) were isolated from blood of donors by density centrifugation over Histopaque-1077 (Sigma, St. Louis, MO) and washed twice with phosphatebuffered saline (PBS) prior to culturing or phenotyping.

\section{Flow Cytometry}

Fresh PBMC samples $\left(5 \times 10^{5}\right.$ cells $)$ were stained with the following antibodies. FITC-conjugated TCR $\delta 1$ (pan TCR $\gamma \delta$ ), V $\delta 1, \mathrm{~V} \delta 2$, and $\mathrm{V} \gamma 9 \mathrm{~T}$ cell subset antibodies were purchased from $\mathrm{T}$ Cell Diagnostics (Cambridge, MA). FITC-conjugated isotype control IgGl Ab was purchased from Sigma. CD4-FITC and CD8-FITC antibodies were purchased from Immunotech (Westbrook, ME). FITC-conjugated pan TCR $\alpha \beta$ antibody was purchased from Becton Dickinson (Mountain View, CA). CD 16-PE Ab was purchased from Antigenix America, Inc. (Franklin Square, NY). The OKT3 hybridoma that produces an anti-CD3 antibody was obtained from ATCC. Hybridoma supernatant was used to stain cells for CD3. These cells were subsequently stained with FITC-conjugated goat anti-mouse secondary antibody purchased from Becton Dickinson. After incubating cell samples with antibodies on ice for $30 \mathrm{~min}$, cells were washed with PBS and then fixed with cold $1 \%$ paraformaldehyde in PBS with gentle vortexing. 5,000 events per sample were collected on a Becton Dickinson FACS SCAN. Data was analyzed by gating on the lymphocyte population and using the Lysis II program (Becton Dick- 
TABLE 1. T and NK lymphocyte distribution among peripheral blood lymphocytes

\begin{tabular}{|c|c|c|c|c|c|c|c|c|c|c|c|c|c|}
\hline & \multicolumn{13}{|c|}{$\%$ of PBL } \\
\hline & \multirow[b]{2}{*}{ Range $^{a}$} & \multicolumn{5}{|c|}{ HIV $^{-}$Donors } & \multicolumn{7}{|c|}{ HIV $^{+}$Donors } \\
\hline & & SN1 & SN2 & SN3 & SN4 & SN5 & SP1 & SP2 & SP3 & SP4 & SP5 & SP6 & SP7 \\
\hline $\mathrm{CD} 3$ & $55-79$ & 79 & 54 & 69 & 81 & 62 & 38 & 52 & 71 & 13 & 81 & 84 & 55 \\
\hline TCR $\alpha \beta$ & $43-76$ & 71 & 46 & 63 & 79 & 50 & 39 & 46 & 65 & 18 & 70 & 78 & 41 \\
\hline TCR $\gamma \delta$ & $1-15$ & 3 & 3 & 5 & 1 & 7 & 4 & 1 & 9 & 2 & 7 & 5 & 1 \\
\hline $\mathrm{CD} 4$ & $33-60$ & 52 & 25 & 39 & 56 & 19 & 9 & 10 & 31 & 6 & 15 & 16 & 8 \\
\hline CD8 & $17-40$ & 28 & 12 & 44 & 27 & 29 & 30 & 33 & 33 & 20 & 58 & 62 & 36 \\
\hline $\mathrm{CD}_{1} 6^{+} \mathrm{CD}^{-}$ & $1-16$ & 7 & 33 & 23 & 8 & 1 & 47 & 21 & 5 & 62 & 4 & 1 & 2 \\
\hline $\mathrm{V} \gamma 9$ & $0.5-10$ & 2.2 & 2.3 & 3.5 & 0.5 & 4.5 & 1.8 & 0.1 & 3.9 & 0.9 & 2.0 & 1.0 & 1.6 \\
\hline $\mathrm{V} \delta 2$ & $0.5-10$ & 2.7 & 2.7 & 1.2 & 0.5 & 4.1 & 0.7 & 0.3 & 0.5 & 0.8 & 0.5 & 0.4 & 1.0 \\
\hline $\mathrm{V} \delta 1$ & $0.5-4$ & 0.4 & 1.6 & nt & nt & nt & 1.1 & 0.2 & 6.3 & 0.4 & nt & $\mathrm{nt}$ & $\mathrm{nt}$ \\
\hline
\end{tabular}

The given figures indicate percentages of cells (gated on lymphocytes) reacting with the corresponding mAbs (see Materials and Methods). For $\mathrm{HIV}^{+}$donors, the absolute $\mathrm{CD}^{+} \mathrm{T}$ cell counts per $1 \mu \mathrm{l}$ of blood were as follows: SPI (409); SP2 (374); SP3 (330); SP4 (22); SP5 (224); SP6 (409); SP7 (110). nt = not tested.

${ }^{a}$ Normal range for HIV-seronegative donors.

inson). Table 1 shows results of flow cytometry analysis from blood donors.

\section{PBMC Cultures}

PBMCs were cultured at $10^{6}$ cells $/ \mathrm{ml}$ in RPMI 1640 medium (Biowhittaker, Walkersville, MD) supplemented with $15 \%$ pooled human $\mathrm{AB}$ serum (Pel-Freeze, Brown Deer, WI), $100 \mathrm{IU} / \mathrm{ml}$ penicillin and $100 \mu \mathrm{g} / \mathrm{ml}$ streptomycin (Mediatech, Herndon, VA), and $2 \mathrm{mM}$ L-glutamine (Mediatech) (complete RPMI medium) alone, or in the presence of $2 \times 10^{5}$ Daudi cells $(11,000$ rads) per ml medium, or $0.1 \mathrm{mM}$ Etpp and 200 U/ml IL-2 (generously provided by Biological Response Modifiers Program, NCI, Frederick, MD), in a humidified atmosphere of $5 \% \mathrm{CO}_{2}$ in air at $37^{\circ} \mathrm{C}$. After 8 or 10 days, the number of live cells per culture was determined by eosin dye exclusion and culture samples were assessed for percentage of $\gamma \delta$ T cells, NK cells, or $\alpha \beta$ T cells by flow cytometry. Lymphocyte subset composition was reported in percentages and relative expansion index (REI), which is the $\gamma \delta \mathrm{T}$ cell percentage resulting after culture with a stimulus divided by the $\gamma \delta \mathrm{T}$ cell percentage after culture with medium alone, or in absolute numbers and times increase over the input number of a particular lymphocyte population.

\section{Cytotoxicity Assays}

Lymphocyte samples from PBMC cultures stimulated with IL-2 or irradiated Daudi cells were tested for capacity to lyse $\mathrm{Na}_{2}\left[{ }^{51} \mathrm{Cr}\right] \mathrm{O}_{4}$ labeled target cells in standard chromium release assays (33). Mycoplasma free target cells, Daudi (34), Raji (35), and K562 (36) were passaged twice weekly in complete RPMI medium containing $10 \%$ FBS (Intergen, Purchase, NY).

\section{T Cell Clones}

Freshly isolated PBMC samples from healthy HIV-seronegative donors were stained with either FITC-conjugated TCR $\delta 1$, anti-V $\delta 1 \mathrm{mAb}$, or with anti-CD4 $\mathrm{mAb}$. Specific $\mathrm{T}$ cell populations were positively selected using a fluorescence-activated cell sorter (FACStar ${ }^{\text {plus }}$, Becton Dickinson) as described (29). Sorted cells were cloned by limiting dilution at 0.7 cell/well in 96 -well round-bottomed microtiter plates (Costar, Cambridge, MA) in complete RPMI 1640 medium with $15 \%$ FBS which was further supplemented with $200 \mathrm{U} / \mathrm{ml} \mathrm{IL-2,} 0.25 \mu \mathrm{g} / \mathrm{ml}$ PHA, $10^{5}$ irradiated $(4,000$ rads) autologous or allogeneic $\mathrm{PBMC} / \mathrm{ml}$ medium and $5 \times 10^{4}$ irradiated (11,000 rads) LCL721 cells/ml (an EBV-transformed lymphoblastoid B-cell line kindly pro- 
vided by Dr. R. DeMars, University of Wisconsin, Madison, WI). Cell cultures were grown in a humidified atmosphere of $5 \% \mathrm{CO}_{2}$ in air at $37^{\circ} \mathrm{C}$. Wells were scored for growth 14 to 21 days after plating. Individual clones were passaged in fresh medium as described above approximately every 10 days, and after expansion, they were phenotyped by flow cytometry using FITC-conjugated $\mathrm{V} \delta 1, \mathrm{~V} \delta 2, \mathrm{~V} \gamma 9, \mathrm{TCR} \alpha \beta$, and CD4 antibodies.

\section{HIV Preparation}

Cell-free virions $\left(\mathrm{HIV}_{\mathrm{LAI}}\right)$ were prepared as described $(37,38)$.

\section{HIV Infection of $T$ Cell Clones}

After at least 7 days since their last passage, $5 \times$ $10^{5}$ cells of each $\mathrm{T}$ cell clone were infected with cell-free $\mathrm{HIV}_{\text {LAI }}$ or mock infected as described (38). Cells were washed extensively to remove residual virus and cultured in complete RPMI medium with $200 \mathrm{U} / \mathrm{ml}$ IL-2. Cell-free supernatants were harvested after the specified culture period and assessed for HIV p24 production by antigen capture ELISA following instructions of the manufacturer (Coulter Corp., Miami, FL).

\section{Proliferation Assay}

After HIV or mock infection, $\mathrm{V} \gamma 9 / \mathrm{V} \delta 2 \mathrm{~T}$ cells were harvested, washed, and plated in triplicate at $5 \times 10^{4}$ cells/well in 96-well flat bottomed microtiter plates in complete RPMI medium with or without $5 \mathrm{U} / \mathrm{ml} \mathrm{IL}-2$, and with or without $5 \times$ $10^{4}$ irradiated Daudi cells (11,000 rads). Plates were incubated in a humidified atmosphere of $5 \% \mathrm{CO}_{2}$ in air at $37^{\circ} \mathrm{C}$. Individual wells were pulsed with $0.25 \mu \mathrm{Ci} /$ well of tritiated thymidine (Du Pont, Boston, MA) 24 hr (and wells in duplicate plates $48 \mathrm{hr}$ ) after the initial exposure to Daudi, and were harvested $24 \mathrm{hr}$ after pulsing. Tritiated thymidine incorporation was measured by liquid scintillation counting. The mean cpm of triplicate samples was used to calculate the stimulation index. Stimulation index for proliferation in response to Daudi cells $=(\gamma \delta \mathrm{T}$ cells with irradiated Daudi cells cpm - irradiated Daudi cells alone $\mathrm{cpm}) /(\gamma \delta \mathrm{T}$ cells in medium alone $\mathrm{cpm})$. Stimulation index for proliferation in response to IL- $2=(\gamma \delta$ T cells with IL- $2 \mathrm{cpm}) /(\gamma \delta \mathrm{T}$ cells alone cpm).

\section{Cytokine-specific Polymerase Chain Reaction (PCR)}

RNA was isolated by guanidinium thiocyanate extraction (39). In brief, $\mathrm{T}$ cell clones (1-2 $\times 10^{5}$ cells) were extensively washed in PBS, resuspended in $400 \mu \mathrm{l}$ of $4 \mathrm{M}$ guanidinium thiocyanate (Bethesda Research Laboratories, Gaithersburg, MD) containing $25 \mathrm{mM}$ sodium citrate, $0.5 \%$ sarcosyl, and $0.1 \mathrm{M} 2$-mercaptoethanol, and vortexed for $10 \mathrm{~min}$. RNA was isolated by addition of $2 \mathrm{M}$ sodium acetate $(40 \mu \mathrm{l})$, chloroform-isoamylalcohol mixture $(24: 1)(160 \mu \mathrm{l})$, and water-saturated phenol $(440 \mu \mathrm{l})$. Samples were vortexed and placed on ice for $5 \mathrm{~min}$ prior to centrifugation $\left(16,000 \times g / 20 \mathrm{~min} / 4^{\circ} \mathrm{C}\right)$. The aqueous phase was transferred to a new Eppendorf tube and an equal volume of isopropanol was added. The precipitated RNA was obtained by incubation at $-70^{\circ} \mathrm{C}$ for $1 \mathrm{hr}$ followed by centrifugation $\left(16,000 \times g / 20 \mathrm{~min} / 4^{\circ} \mathrm{C}\right)$. The precipitated RNA was washed three times in $80 \%$ ethanol with $20 \%$ DEPC $\mathrm{H}_{2} \mathrm{O}$, dried, and then resuspended in DEPC $\mathrm{H}_{2} \mathrm{O}$ containing 0.1 $\mathrm{U} / \mu \mathrm{l}$ RNAsin (Promega, Madison, WI). These RNA preparations were used for cytokine-specific RT-PCR. One microliter sample containing $25 \mathrm{ng}$ of RNA was added to $4 \mu \mathrm{l}$ of reverse transcription mixture $\left(5 \mathrm{mM} \mathrm{MgCl}_{2}\right.$ [Perkin Elmer Cetus, Norwalk, CT], $1 \times$ PCR buffer II [Perkin Elmer Cetus], $1 \mathrm{mM}$ each of dNTPs [Perkin Elmer Cetus], $1 \mathrm{U} / \mu \mathrm{l}$ RNase inhibitor [Perkin Elmer Cetus], $2.5 \mathrm{U} / \mu \mathrm{l}$ SuperScript II [Life Technologies, Gaithersburg, MD], and $2.5 \mu \mathrm{M}$ oligo [dT] 16 [Perkin Elmer Cetus]) $(40,41)$. Each sample was overlayed with light mineral oil (Sigma). Tubes were then placed in a thermal cycler (Perkin Elmer Cetus) and incubated for $15 \mathrm{~min}$ at $42^{\circ} \mathrm{C}$, followed by $5 \mathrm{~min}$ at $99^{\circ} \mathrm{C}$ and then for $5 \mathrm{~min}$ at $5^{\circ} \mathrm{C}$. Following reverse transcription, 20 $\mu l$ of PCR mix was added to each tube to give a final concentration of $0.625 \mathrm{U} / 20 \mu \mathrm{l}$ AmpliTaq DNA polymerase (Perkin Elmer Cetus), $0.15 \mu \mathrm{M}$ 5' primer, $0.15 \mu \mathrm{M}$ 3' primer, $2 \mathrm{mM} \mathrm{MgCl}_{2}$, and $1 \times$ PCR buffer II (Perkin Elmer Cetus). Primers specific for human IFN- $\gamma$, IL-2, IL-4, IL-5, IL-6, IL-10, IL-13, and $\beta$-actin were obtained from Clontech Laboratories, Inc. (Palo Alto, CA) or prepared by the UAB Cytokine Core Facility (41). After heating at $95^{\circ} \mathrm{C}$ for $2 \mathrm{~min}$, cDNAs were amplified for 35 cycles, each cycle consisting of $95^{\circ} \mathrm{C}$ for $1 \mathrm{~min}, 60^{\circ} \mathrm{C}$ for $1 \mathrm{~min}$, and extended at $60^{\circ} \mathrm{C}$ for $7 \mathrm{~min}$, and then stored at $4^{\circ} \mathrm{C}$ until analyzed. PCR products were separated by electrophoresis in $2 \%$ agarose gels, stained 
TABLE 2. Daudi cell stimulated PBMCs and their cytotoxic activity

\begin{tabular}{|c|c|c|c|c|c|c|c|}
\hline \multirow[b]{2}{*}{ Donor } & \multirow[b]{2}{*}{ Culture } & \multicolumn{2}{|c|}{$\gamma \delta$} & \multirow[b]{2}{*}{$\mathbf{E}: \mathbf{T}$} & \multicolumn{3}{|c|}{ \% Specific Lysis } \\
\hline & & $\%$ & $\mathbf{R E I}^{a}$ & & Daudi & Raji & K562 \\
\hline \multirow[t]{4}{*}{ SNl } & Medium only & 1.6 & & & & & \\
\hline & Med. + Daudi & 21.3 & 13.3 & $9: 1$ & 72 & 42 & 43 \\
\hline & & & & $3: 1$ & 76 & 44 & $\mathrm{nt}$ \\
\hline & & & & $1: 1$ & 70 & 24 & $\mathrm{nt}$ \\
\hline \multirow[t]{4}{*}{ SN2 } & Medium only & 1.6 & & & & & \\
\hline & Med. + Daudi & 55.3 & 34.6 & $9: 1$ & 74 & 55 & 83 \\
\hline & & & & $3: 1$ & 73 & 61 & $\mathrm{nt}$ \\
\hline & & & & $1: 1$ & 57 & 37 & nt \\
\hline \multirow[t]{4}{*}{ SPl } & Medium only & 2.7 & & & & & \\
\hline & Med. + Daudi & 3.8 & 1.4 & $9: 1$ & 30 & 78 & 60 \\
\hline & & & & $3: 1$ & 17 & 25 & $\mathrm{nt}$ \\
\hline & & & & $1: 1$ & 13 & 50 & $\mathrm{nt}$ \\
\hline \multirow[t]{4}{*}{ SP2 } & Medium only & 1.1 & & & & & \\
\hline & Med. + Daudi & 0.5 & 0.5 & $9: 1$ & 1 & 4 & 0 \\
\hline & & & & $3: 1$ & 3 & 0.5 & $\mathrm{nt}$ \\
\hline & & & & $1: 1$ & 0.2 & 1.0 & $\mathrm{nt}$ \\
\hline \multirow[t]{4}{*}{ SP3 } & Medium only & 2.7 & & & & & \\
\hline & Med. + Daudi & 39.4 & 14.6 & $9: 1$ & 73 & 48 & 57 \\
\hline & & & & $3: 1$ & 78 & 45 & $\mathrm{nt}$ \\
\hline & & & & $1: 1$ & 71 & 26 & $\mathrm{nt}$ \\
\hline \multirow[t]{2}{*}{ SP4 } & Medium only & 0.7 & & & & & \\
\hline & Med. + Daudi & 0.7 & 1.0 & $3: 1$ & 12 & 20 & 0 \\
\hline
\end{tabular}

$2.5 \times 10^{6}$ PBMCs from each donor were cultured in the presence of the indicated stimuli for 10 days and assayed for their ability to lyse the indicated target cells. Percentage of $\gamma \delta^{+} \mathrm{T}$ cells was determined by reactivity with TCR $\delta 1$ mAb as described in Materials and Methods. $\mathrm{nt}=$ not tested.

${ }^{a}$ REI (relative expansion index) was calculated as the $\gamma \delta \mathrm{T}$ cell percentage resulting after culture with a stimulus divided by the $\gamma \delta \mathrm{T}$ cell percentage after culture in medium alone.

with ethidium bromide, and visualized by UV light illumination.

\section{RESULTS}

\section{Functional $\gamma \delta \mathrm{T}$ Cell Defect in HIV-Seropositive Persons}

To assess responsiveness of $\gamma \delta \mathrm{T}$ cells, PBMC samples from each donor were cultured in the presence of irradiated Daudi cells (30) or in medium alone. After 10 days of culture, the relative expansion of $\gamma \delta$ T cells was assessed (Tables 2 and $3)$. As anticipated, $\gamma \delta \mathrm{T}$ cells from all five seronegative donors (SN1, SN2, SN3, SN4, and SN5) responded well to Daudi cells. However, only $\gamma \delta$ $\mathrm{T}$ cells from one out of seven HIV+ persons (SP3) responded to the Daudi stimulus (Tables 2 and 3 ) and (similar to controls) expressed the characteristic $\mathrm{V} \gamma 9 / \mathrm{V} \delta 2$ TCRs (data not shown). In contrast, $\gamma \delta \mathrm{T}$ cells from the other HIV+ individuals (SP1, SP2, SP4, SP5, SP6, and SP7) failed to proliferate in response to Daudi. To estimate $\gamma \delta \mathrm{T}$ cell cytotoxic function, samples of the bulk Daudi-stimulated cultures (SN1, SN2, SP1, SP2, SP3, and SP4) were tested for their ability to lyse Daudi, Raji, and K562 target cells (Table 2). Typically, $\mathrm{V} \gamma 9 / \mathrm{V} \delta 2 \mathrm{~T}$ cells lyse Daudi and $\mathrm{K} 562$ cells substantially better than Raji cells (29). This pattern of differential lysis was displayed by effector 
TABLE 3. Response of $\gamma \delta \mathrm{T}$ lymphocytes to Daudi cells or Etpp

\begin{tabular}{|c|c|c|c|c|c|c|c|c|c|c|c|c|c|}
\hline \multirow[b]{3}{*}{ T Cell Subset } & \multirow[b]{3}{*}{ Stimuli } & \multicolumn{12}{|c|}{ Times Increase per T Cell Subset after Culture } \\
\hline & & \multicolumn{5}{|c|}{ HIV $^{-}$Donors $^{a}$} & \multicolumn{7}{|c|}{ HIV $^{+}$Donors } \\
\hline & & SN1 & SN2 & SN3 & SN4 & SN5 & SP1 & SP2 & SP3 & SP4 & SP5 & SP6 & SP7 \\
\hline TCR $\gamma \delta$ & Daudi & 4.0 & 6.2 & 5.6 & 4.9 & 3.2 & 0 & 0 & 1.6 & 0 & 0 & 0 & 0 \\
\hline TCR $\gamma \delta$ & Etpp & 17 & 22 & $\mathrm{nt}$ & nt & $\mathrm{nt}$ & 0 & 0 & 1.5 & 0 & nt & $\mathrm{nt}$ & nt \\
\hline TCR $\alpha \beta$ & Daudi & 0 & 0 & 1.1 & 0 & 0 & 0 & 0 & 0 & 0 & 0 & 0 & 0 \\
\hline TCR $\alpha \beta$ & Etpp & 0 & 0 & $\mathrm{nt}$ & $\mathrm{nt}$ & $\mathrm{nt}$ & 0 & 0 & 0 & 0 & nt & nt & nt \\
\hline
\end{tabular}

PBMCs from each donor were cultured in the presence of either irradiated Daudi cells, or Etpp and IL-2 (to achieve a maximal response) as described in Materials and Methods. After 8 days, the resulting times increase over the input number of the particular lymphocyte population was measured. The input numbers of $\alpha \beta / \gamma \delta \mathrm{T}$ cells (in millions) for each set of cultures were as follows: SN1, 1.32/0.053; SN2, 0.90/0.042; SN3, 0.49/0.035; SN4, 0.72/0.010; SN5, 0.38/0.053; SP1, 0.87/0.072; SP2, 0.76/0.020; SP3, 1.14/0.80; SP4, 0.28/0.006; SP5, 0.42/0.043; SP6, 0.72/0.043; SP7, 0.34/0.009. $0=$ no increase above the input number; $\mathrm{nt}=$ not tested.

${ }^{a}$ In a separate experiment, $\mathrm{V} \gamma 9 / \mathrm{V} \delta 2 \mathrm{~T}$ cells from 32 out of 32 putatively healthy blood donors responded positively to a different batch of Daudi cells (see Discussion). Since different batches and passages of Daudi cells differ slightly in their stimulatory activities for $\mathrm{V} \gamma 9 / \mathrm{V} \delta 2 \mathrm{~T}$ cells, this experiment has qualitative rather than quantitative significance in the context of present data.

cells from donors SN1, SN2, and SP3, but not by cells from donors SP1, SP2, and SP4. In fact, the Daudi stimulated cultures SP2 and SP4 did not lyse any of the targets (except for a weak lysis of Raji cells by SP4 responders). Thus, in experiments performed with PBMC from seven SP donors representing various $\mathrm{CDC}$ stages of HIV infection, only $\gamma \delta \mathrm{T}$ cells from one donor (SP3) proliferated weakly in response to Daudi cells (Tables 2 and 3). Furthermore, the addition of IL-2 to cultures containing irradiated Daudi cells was not able to restore Daudi-specific responsiveness of $\mathrm{V} \gamma 9 / \mathrm{V} \delta 2 \mathrm{~T}$ cells from nonresponsive SP donors (data not shown). PBMC responses to Etpp, a nonpeptide antigen which specifically stimulates $\mathrm{V} \gamma 9 / \mathrm{V} \delta 2 \mathrm{~T}$ cells, corresponded to those elicited by irradiated Daudi cells (Table 3 ). Therefore, although $\gamma \delta$ T cells are present in the peripheral blood of HIV+ individuals, the major peripheral blood $\gamma \delta \mathrm{T}$ cell subpopulation, the $\mathrm{V} \gamma 9 / \mathrm{V} \delta 2 \mathrm{~T}$ cell subset, is refractory to the constitutive TCR stimuli.

\section{HIV Infection of $\boldsymbol{\gamma} \delta$ T Cells in Vitro}

One $\alpha \beta$ and three distinct $\gamma \delta \mathrm{T}$ cell clones were exposed to cell-free HIV in vitro. The $\alpha \beta$ T cell clone (VM22-5) and one of the $\gamma \delta \mathrm{T}$ cell clones (VM4-4 $\mathrm{V} \gamma 9^{+} / \mathrm{V} \delta 2^{+}$) were $\mathrm{CD}^{+}$, whereas the other two $\gamma \delta \mathrm{T}$ cell clones (VM3-3 $\mathrm{V} \gamma 9^{-} / \mathrm{V} \delta 1^{+}$ and $\mathrm{VM} 9-3 \mathrm{~V} \gamma 9^{+} / \mathrm{V} \delta 2^{+}$) were $\mathrm{CD} 4^{-}$when analyzed by flow cytometry (Fig. 1). The exposure to HIV resulted in productive infection in all four clones (Table 4). One week after infection, the expression of cytokine mRNAs was compared with that of mock-infected corresponding clones (Fig. 2). HIV infection did not have any substantial measurable effect on the expression levels of IFN- $\gamma$, IL-2, IL-4, IL-5, IL-6, IL-10, and IL-13 mRNAs as assessed by semiquantitative RT-PCR. The predominantly expressed cytokine mRNAs in the $\gamma \delta \mathrm{T}$ cell clones were those coding for IFN- $\gamma$, IL-5, IL-6, and IL-10 (Fig. 2). It is noteworthy that HIV infection of $\mathrm{V} \gamma 9 / \mathrm{V} \delta 2 \mathrm{~T}$ cells did not influence their responsiveness to Daudi cells, although it somewhat decreased their capacity to respond to IL-2 (Table 5).

\section{DISCUSSION}

Studies by Bukowski et al. utilizing Jurkat TCR transfectants have demonstrated clearly that the recognition of both Daudi cells and monoalkyl phosphates is mediated through the $\mathrm{V} \gamma 9 / \mathrm{V} \delta 2$ TCR (42). Our results indicate that despite the physical presence of peripheral $\mathrm{V} \gamma 9 / \mathrm{V} \delta 2 \mathrm{~T}$ cells in HIV+ individuals, their functional TCR-mediated capacity to respond to constitutive antigens is largely absent or severely diminished. The 

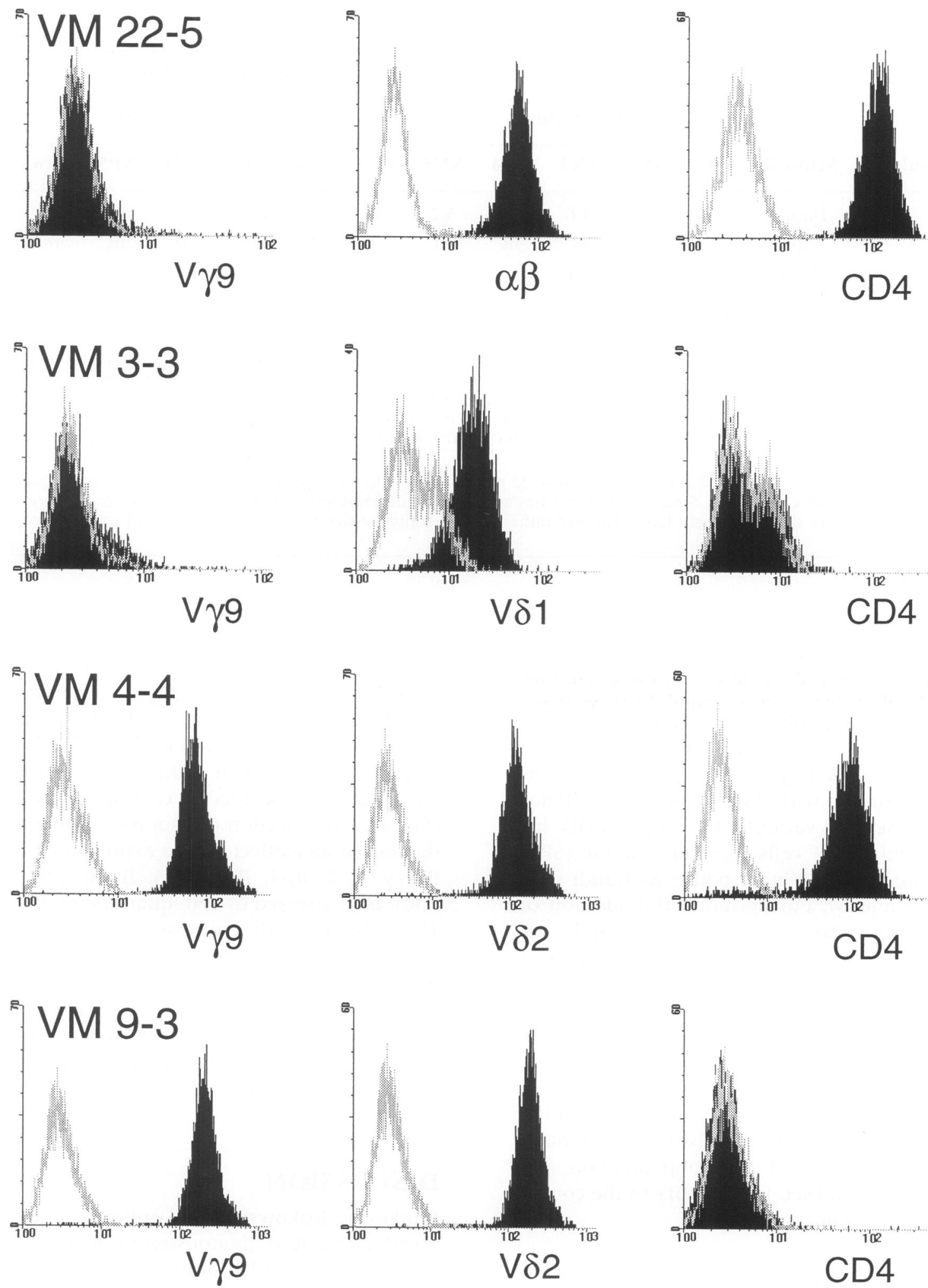

FIG. 1. Phenotype of $T$ cell clones utilized in HIV-infection experiments

Four T cell clones designated VM 22-5, VM 3-3, VM 4-4, and VM 9-3 were isolated from one HIV-seronegative donor and phenotyped for reactivity to FITC conjugated TCR mAbs specific for V $\gamma 9$, V $\delta 2$, V $\delta 1$, or $\alpha \beta$, and reactivity to anti-CD4-FITC mAb by flow cytometry. Isotype control antibody IgG l-FITC reactivity is shown in gray outline. 
TABLE 4. Production of HIV p24 by HIV-infected $T$ cell clones

\begin{tabular}{lcc}
\hline $\begin{array}{l}\text { TCell } \\
\text { Clone }\end{array}$ & Phenotype & p24 pg/ml \\
\hline $\mathrm{VM} \mathrm{22-5}$ & $\alpha \beta \mathrm{CD}^{+} \mathrm{CD} 8^{-}$ & 1381 \\
$\mathrm{VM} \mathrm{3-3}$ & $\mathrm{V} \gamma 9^{-} / \mathrm{V} \delta 1^{+} \mathrm{CD} 4^{-} \mathrm{CD} 8^{-}$ & 1050 \\
$\mathrm{VM} \mathrm{4-4}$ & $\mathrm{V} \gamma 9^{+} / \mathrm{V} \delta 2^{+} \mathrm{CD} 4^{+} \mathrm{CD} 8^{-}$ & 663 \\
$\mathrm{VM} 9-3$ & $\mathrm{~V} \gamma 9^{+} / \mathrm{V} \delta 2^{+} \mathrm{CD} 4^{-} \mathrm{CD} 8^{+}$ & 1180 \\
\hline
\end{tabular}

$\mathrm{T}$ cell clones from one HIV-seronegative donor were either infected with HIV $\mathrm{LAI}_{\mathrm{L}}$ or were mock infected. Six days later, cell free supernatants from these cultures were assessed for presence of viral core antigen, p24. Supernatants from mock infected cells did not exceed the OD of negative controls. The results are representative of two experiments.

Daudi-specific reactivity of $\mathrm{V} \gamma 9 / \mathrm{V} \delta 2$ TCR-bearing lymphocytes $(29,30)$ is one of the most robust specific physiologic reactivities of human lymphocytes. For example, in one set of experiments, more than a log increase in $\mathrm{V} \gamma 9 / \mathrm{V} \delta 2 \mathrm{~T}$ cell numbers was measured in PBMC samples from 32 volunteers after a l-week in vitro exposure to irradiated Daudi cells (mean times increase $\pm S D=11.7 \pm 3.6$; P. Fisch, unpublished data). Therefore, it was very surprising to observe such a profound lack of $\mathrm{V} \gamma 9 / \mathrm{V} \delta 2 \mathrm{~T}$ cell response in relatively healthy and asymptomatic donors SP1 and SP2. It is possible that this functional $\gamma \delta \mathrm{T}$ cell deficit contributes to the augmented susceptibility to opportunistic infection and various neoplasms typically associated with HIV infections (8). In addition, since $\gamma \delta \mathrm{T}$ cells may no longer participate in the process of eliminating HIV-infected cells in the later stages of HIV infection, the overall levels of HIV infection may increase during the period of $\mathrm{V} \gamma 9 / \mathrm{V} \delta 2 \mathrm{~T}$ cell function suppression.

Natural or genetically engineered (transfection) expression of the CD4 molecule on the surface of human cells renders them susceptible to HIV infection (43). Nevertheless, some human cells negative for CD4 by immunofluorescence are infectable with HIV. These cells were shown to express low levels of CD4 mRNA (44), which is likely to result in meager (undetectable by flow cytometry) cell-surface CD4 expression sufficient for productive HIV infection. Fluorocytometric analyses indicating that some $\gamma \delta \mathrm{T}$ cells which initially do not express the CD4 glycoprotein on the cell surface become either "dimly" cell-sur- face CD4-positive when grown in vitro and stimulated with IL-2 (M. Malkovsky and P. Fisch, unpublished data), or strongly cell-surface CD4positive after HHV-6 infection (23), support this hypothesis. Our in vitro $\gamma \delta \mathrm{T}$ cell infectivity data reported here suggest that many more $\gamma \delta$ T cells in the peripheral blood may be infectable with HIV than the $1 \%$ of total $\gamma \delta$ T cells that score as $\mathrm{CD} 4{ }^{+}$by immunofluorescence (12). The potential contribution of in vivo HIV infection of $\gamma \delta \mathrm{T}$ cells to functional impairment and/or depletion of this lymphocyte subset in HIV-seropositive individuals merits detailed investigations. It is conceivable that direct HIV infection of $\mathrm{V} \gamma 9 / \mathrm{V} \delta 2 \mathrm{~T}$ cells may eventually render them nonresponsive to stimuli such as alkyl phosphates derived from mycobacteria that may be encountered in vivo. However, our in vitro experiments demonstrate that several days after HIV infection, $\mathrm{V} \gamma 9 / \mathrm{V} \delta 2 \mathrm{~T}$ cells proliferate in response to Daudi cells and synthesize cytokine specific mRNA at levels comparable to mock-infected cells. Although these results do not support the possibility that the infection of $\gamma \delta$ T cells with HIV would be responsible for the observed defect, they indicate that infected $\gamma \delta \mathrm{T}$ cells may constitute a previously unrecognized in vivo reservoir for HIV.

Our previous study which detected cytotoxic responses by $\mathrm{V} \gamma 9 / \mathrm{V} \delta 2 \mathrm{~T}$ cell clones against HIVinfected cells (18) indicates that this $\mathrm{T}$ cell subset may recognize a stimulatory ligand on the surface of HIV-infected cells. In light of the fact that $\gamma \delta \mathrm{T}$ cells display an increased susceptibility for activation-induced apoptosis $(45,46)$, it is possible to speculate that continuous stimulation with HIV-associated antigen(s) leads eventually to $\mathrm{V} \gamma 9 / \mathrm{V} \delta 2 \mathrm{~T}$ cell death or anergy. Indeed, Poccia et al. (47) have reported recently that in $60 \%$ of asymptomatic HIV+ persons, peripheral V $\delta 2 \mathrm{~T}$ cells exhibited a functional anergy to Daudi and mycobacterial stimulations. Similar to our results, the $\gamma \delta \mathrm{T}$ cell functional defect was not corrected by adding exogenous IL-2. In contrast, in the study of Wesch et al. (48), the defective response of $\mathrm{V} \gamma 9 \mathrm{~T}$ cells from HIV+ persons to heat-killed Mycobacterium tuberculosis was restored by exogenous IL-2. Since we did not study the response to Mycobacterium tuberculosis, the results by Wesch et al. (48) are not directly comparable to ours. However, the reason for the difference between the positive effect of IL-2 in restoring $\mathrm{V} \gamma 9 / \mathrm{V} \delta 2 \mathrm{~T}$ cell responsiveness to heatkilled mycobacteria in HIV+ persons (48) and the lack of effect in the study by Poccia et al. (47), which measured responses to TUBAg-1, a myco- 

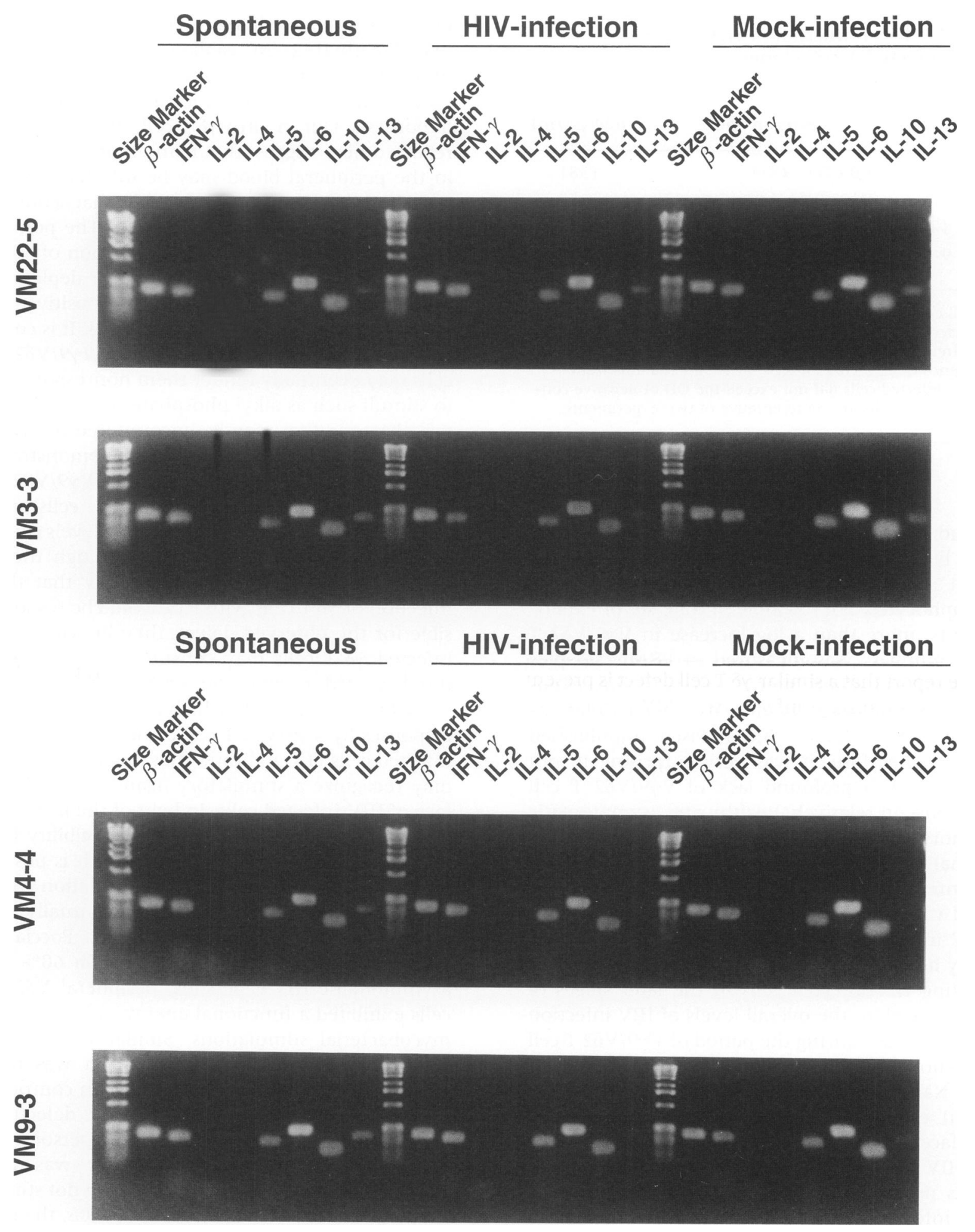

FIG. 2. Characterization of Th1 and Th2 cytokine profiles in human $\gamma \delta$ and $\alpha \beta$ T cell clones RNA was isolated from $\gamma \delta$ and $\alpha \beta$ T cell clones designated as VM22-5 ( $\left.\alpha \beta^{+}, \mathrm{CD}^{+}, \mathrm{CD}^{-}\right), \mathrm{VM} 3-3$ (V $\gamma 9^{-}$, $\left.\mathrm{V} \delta 1^{+}, \mathrm{CD}^{-}, \mathrm{CD}^{-}\right), \mathrm{VM} 4-4\left(\mathrm{~V} \gamma 9^{+} / \mathrm{V} \delta 2^{+}, \mathrm{CD} 4^{+}, \mathrm{CD} 8^{-}\right)$, and $\mathrm{VM} 9-3\left(\mathrm{~V} \gamma 9^{+} / \mathrm{V} \delta 2^{+}, \mathrm{CD} 4^{-}, \mathrm{CD} 8^{+}\right) 1$ week after feeding with PHA, IL-2, and irradiated feeder cells (spontaneous) as described in Materials and Methods, or 1 week after HIV or mock infection. The RNA samples were then subjected to TH1 and TH2 RT-PCR. The size of $494 \mathrm{bp}, 458 \mathrm{bp}, 462 \mathrm{bp}, 414$ bp, $628 \mathrm{bp}, 352 \mathrm{bp}$, and 285 bp PCR product bands represent IFN- $\gamma$, IL-2-, IL-4-, IL-5-, IL-6-, IL-10-, and IL-13-specific messages, respectively. 
TABLE 5. Proliferation of HIV- or mock-infected $\mathrm{V} \gamma 9 / \mathrm{V} \delta 2 \mathrm{~T}$ cells

\begin{tabular}{llll}
\hline & & \multicolumn{2}{c}{$\begin{array}{c}\text { Stimulation } \\
\text { Index }\end{array}$} \\
\cline { 3 - 4 } Infection & Pulsed $^{\boldsymbol{b}}$ & Daudi & IL-2 \\
\hline Mock & 24 hours & 4.6 & 7.7 \\
HIV & 24 hours & 5.1 & 3.4 \\
Mock & 48 hours & 2.6 & 7.9 \\
HIV & 48 hours & 2.2 & 3.1 \\
\hline
\end{tabular}

$\mathrm{V} \gamma 9 / \mathrm{V} \delta 2 \mathrm{~T}$ cells (clone HH4) were either infected with HIV $_{\text {LAI }}$ or mock infected. Infection status was confirmed by p24 assay of cell free culture supernatant. After 18 days of culture, cells were harvested and tested for the ability to proliferate in response to Daudi cells, $5 \mathrm{U} / \mathrm{ml} \mathrm{IL-2,} \mathrm{or} \mathrm{me-}$ dium alone as described in Materials and Methods.

${ }^{a}$ Wells were pulsed with tritiated thymidine 24 or $48 \mathrm{hr}$ after exposure to the stimuli.

${ }^{b}$ Data are reported as stimulation indices (see Materials and Methods).

bacteria-derived nonpeptidic antigen, is unclear. The report that a similar $\gamma \delta \mathrm{T}$ cell defect is present in rhesus monkeys infected with SIV (49) is compatible with Poccia's, Wesch's, and our study.

The development of anti-viral therapies as well as the implementation of effective immunebased strategies to inhibit HIV disease progression rest on understanding the complex nature the immune mechanism dysfunctions associated with HIV infection. Potentially, the functional $\mathrm{V} \gamma 9 / \mathrm{V} \delta 2$ T-cell hypo- or unresponsiveness in HIV + individuals may result in both detrimental and beneficial homeostatic influences. For example, hyporesponsive $\mathrm{V} \gamma 9 / \mathrm{V} \delta 2 \mathrm{~T}$ cells may be less effective in contributing to immunosurveillance of HIV, tumor cells, and opportunistic pathogens, but the overall immunological activation that is thought to be one of the driving forces of AIDS pathogenesis (1) may be substantially lower when the majority of $\gamma \delta \mathrm{T}$ cells are hyporesponsive.

\section{ACKNOWLEDGMENTS}

We thank Drs. Franklin M. Graziano, and H. Goldstein for their help in obtaining human blood samples, Dr. M. Merle Elloso for helpful discussion, and Ms. K. Elmer for assistance with flow cytometry. This work was supported by grants from the NIH and the Tracy, Jamie and
Dawn Ruhrup Memorial Virus Research Fund. This is publication no. 36-052 of WRPRC.

\section{REFERENCES}

1. Pantaleo G, Fauci AS. (1995) New concepts in the immunopathogenesis of HIV infection. Annu. Rev. Immunol. 13: 487-512.

2. Daar ES, Moudgil T, Meyer RD, Ho DD. (1991) Transient high levels of viremia in patients with primary human immunodeficiency virus type 1 infection. $N$. Engl. J. Med. 324: 961-964.

3. Clark SJ, Saag MS, Decker WD, et al. (1991) High titers of cytopathic virus in plasma of patients with symptomatic primary HIV-1 infection. N. Engl. J. Med. 324: 961-964.

4. Tindall B, Cooper DA. (1991) Primary HIV infection: Host responses and intervention strategies. AIDS 5: 1-14.

5. Wei X, Ghosh SK, Taylor ME, et al. (1995) Viral dynamics in human immunodeficiency virus type 1 infection. Nature 373: 117-122.

6. Ho DD, Neumann AU, Perelson AS, Chen W, Leonard JM, Markowitz M. (1995) Rapid turnover of plasma virions and CD4 lymphocytes in HIV-1 infection. Nature 373: 123 126.

7. Perelson AS, Neumann AU, Markowitz M, Leonard JM, Ho DD. (1996) HIV-1 dynamics in vivo: Virion clearance rate, infected cell life-span, and viral generation time. Science 271: 1582-1586.

8. Dalgleish AG, Malkovsky M. (1988) AIDS and the new viruses. In: Webster ADB (ed) Immunodeficiency and Disease. Kluwer Academic Publishers, London, pp. 1-24.

9. Fauci AS, Lane HC. (1994) Human immunodeficiency virus (HIV) disease. AIDS and related disorders. In: Isselbacher $\mathrm{KJ}, \mathrm{Braun}-$ wald E, Wilson JD, Martin JB, Fauci AS, Kasper DL (eds) Harrison's Principles of Internal Medicine. McGraw-Hill, Inc., New York, pp. 1566-1618.

10. Wallace $M$, Malkovsky M, Carding S. (1995) Gamma/delta T lymphocytes in viral infections. J. Leukoc. Biol. 58: 277-283.

11. Lanier LL, Ruitemberg J, Bolhuis RHL, Borst J, Phillips J, Testi R. (1988) Structural and serological heterogeneity of $\gamma \delta \mathrm{T}$ cell antigen receptor expression in thymus and peripheral blood. Eur. J. Immunol. 18: 1985-1992.

12. Groh V, Porcelli S, Fabbi M, et al. (1989) Human lymphocytes bearing T-cell receptor 
$\gamma \delta$ are phenotypically diverse and evenly distributed throughout the lymphoid system. J. Exp. Med. 169: 1277-1294.

13. Deusch K, Luling F, Reich $K$, Classen $M$, Wagner H, Pfeffer K. (1991) A major fraction of human intraepithelial lymphocytes simultaneously expresses the $\gamma \delta \mathrm{T}$ cell receptor, the CD8 accessory molecule and preferentially uses the V $\delta 1$ gene segment. Eur. J. Immunol. 21: 1053-1059.

14. Parker CM, Groh V, Band H, et al. (1990) Evidence for extrathymic changes in the $\mathrm{T}$ cell receptor $\gamma \delta$ repertoire. J. Exp. Med. 171: 1597-1612.

15. Haas W, Pereira P, Tonegawa S. (1993) Gamma/delta cells. Annu. Rev. Immunol. 11: 637-685.

16. Morita CT, Beckman EM, Bukowski JF, et al. (1995) Direct presentation of nonpeptide prenyl pyrophosphate antigens to human $\gamma \delta$ T cells. Immunity 3: 495-507.

17. Tanaka Y, Morita CT, Tanaka Y, Nieves E, Brenner MB, Bloom BR. (1995) Natural and synthetic nonpeptide antigens recognized by human $\gamma \delta$ T cells. Nature 375: 155-158.

18. Wallace $M$, Bartz SR, Chang W-L, MacKenzie D, Pauza CD, Malkovsky M. (1996) $\gamma \delta \mathrm{T}$ lymphocyte responses to human immunodeficiency virus. Clin. Exp. Immunol. 103: 177-184.

19. Malkovsky M. (1992) The function and specificity of $\gamma \delta \mathrm{T}$ cells. Vaccine Res. 1: 183191.

20. Malkovsky M, Bartz SR, MacKenzie D, et al. (1992) Are $\gamma \delta$ T cells important for the elimination of virus-infected cells? J. Med. Primatol. 21: 113-118.

21. Maccario R, Revello MG, Comoli P, Montagna D, Locatelli F, Gerna G. (1993) HLAunrestricted killing of HSV-1 infected mononuclear cells. J. Immunol. 150: 1437-1445.

22. Bukowski JF, Morita CT, Brenner MB. (1994) Recognition and destruction of virusinfected cells by human $\gamma \delta$ CTL. J. Immunol. 153: 5133-5140.

23. Lusso P, Garzino-Demo A, Crowley RW, Malnati MS. (1995) Infection of $\gamma \delta \mathrm{T}$ lymphocytes by human herpesvirus 6: Transcriptional induction of CD4 and susceptibility to HIV infection. J. Exp. Med. 181: 13031310.

24. Autran B, Triebel F, Katlama C, Rozenbaum W, Hercend T, Debre P. (1989) T cell receptor $\gamma / \delta^{+}$lymphocyte subsets during HIV infection. Clin. Exp. Immunol. 75: 206-210.
25. De Paoli $\mathrm{P}$, Gennari $\mathrm{D}$, Martelli $\mathrm{P}$, et al. (1991) A subset of $\gamma \delta$ T lymphocytes is increased during HIV-1 infection. Clin. Exp. Immunol. 83: 187-191.

26. De Maria A, Ferrazin A, Ferrini S, Ciccone E, Terragna A, Moretta L. (1991) Selective increase of a subset of $\mathrm{T}$ cell receptor $\gamma \delta \mathrm{T}$ lymphocytes in the peripheral blood of patients with human immunodeficiency virus type 1 infection. J. Infect. Dis. 165: 917-919.

27. Hinz $T$, Wesch D, Friese $K$, Reckziegel A, Arden B, Kabelitz D. (1994) T cell receptor $\gamma \delta$ repertoire in HIV-1-infected individuals. Eur. J. Immunol. 24: 3044-3049.

28. Boullier S, Cochet $M$, Poccia F, Gougeon M-L. (1995) CDR3-independent $\gamma \delta \mathrm{V} \delta 1^{+} \mathrm{T}$ cell expansion in the peripheral blood of HIV-infected persons. J. Immunol. 154: 1418-1431.

29. Fisch P, Malkovsky M, Braakman E, et al. (1990) $\gamma \delta \mathrm{T}$ cell clones and natural killer cell clones mediate distinct patterns of non-major histocompatibility complex-restricted cytolysis. J. Exp. Med. 171: 1567-1579.

30. Fisch P, Malkovsky M, Kovats S, et al. (1990) Recognition by human $\mathrm{V} \gamma 9 / \mathrm{V} \delta 2 \mathrm{~T}$ cells of a GroEL homolog on Daudi Burkitt's lymphoma cells. Science 250: 1269-1273.

31. Tanaka Y, Sano S, Nieves E, et al. (1994) Nonpeptide ligands for human $\gamma \delta \mathrm{T}$ cells. Proc. Natl. Acad. Sci. U.S.A. 91: 8175-8179.

32. Scharko AM, Graziano FM, Malkovsky M, Pauza CD, Wallace M. (1995) Persistent non-B cell lymphocytosis in HIV infected individuals. Immunol. Lett. 48: 157-158.

33. Malkovsky M, Asherson GL, Stockinger B, Watkins MC. (1982) Nonspecific inhibitor released by $\mathrm{T}$ acceptor cells reduces the production of interleukin-2. Nature 300: 652655.

34. Klein E, Klein G, Nadkarni JS, Nadkarni JJ, Wigzell H, Clifford P. (1968) Surface IgMkappa specificity on a Burkitt Lymphoma cell in vivo and in derived culture lines. Cancer Res. 28: 1300-1310.

35. Pulvertaft RJV. (1964) Cytology of Burkitt's tumour (African lymphoma). Lancet i: 238240.

36. Lozzio CB, Lozzio BB. (1975) Human chronic myelogenous leukemia cell-line with positive Philadelphia chromosome. Blood 45: 321-334.

37. Bartz SR, Pauza CD, Ivanyi J, Jindal S, Welch WJ, Malkovsky M. (1994) An Hsp60 
related protein is associated with purified HIV and SIV. J. Med. Primatol. 23: 151-154.

38. Bartz SR, Hohenwalter E, Hu M-K, Rich DH, Malkovsky M. (1995) Inhibition of HIV-1 replication by nonimmunosuppressive analogs of cyclosporin A. Proc. Natl. Acad. Sci. U.S.A. 92: 5381-5385.

39. Chomczynski P, Sacchi N. (1987) Single-step method of RNA isolation by acid guanidinium thiocyanate-phenol-chloroform extraction. Anal. Biochem. 162: 156-159.

40. Fujihashi K, Yamamoto $M$, McGhee JR, Kiyono H. (1993) $\alpha \beta$ T cell receptor-positive intraepithelial lymphocytes with $\mathrm{CD}^{+}$, $\mathrm{CD} 8^{-}$and $\mathrm{CD}^{+}, \mathrm{CD}^{+}$phenotypes from orally immunized mice provide Th-2 like function for B cell responses. J. Immunol. 151: 6681-6691.

41. Fujihashi $K$, Yamamoto $M$, Hiroi $T$, Barnberg TV, McGhee JR, Kiyono H. (1996) Selected Th 1 and Th2 cytokine mRNA expression by $\mathrm{CD}^{+}{ }^{+} \mathrm{T}$ cells isolated from inflamed human gingival tissues. Clin. Exp. Immunol. 103: 422-428.

42. Bukowski JF, Morita CT, Tanaka Y, Bloom BR, Brenner MB, Band H. (1995) V $\gamma 2$ V $\delta 2$ TCR-dependent recognition of non-peptide antigens and Daudi cells analyzed by TCR gene transfer. J. Immunol. 154: 998-1006.

43. Maddon PJ, Dalgleish AG, McDougal JS, Clapham PR, Weiss RA, Axel R. (1986) The T4 gene encodes the AIDS virus receptor ans is expressed in the immune system and the brain. Cell 47: 333-348.

44. Malkovsky M, Philpott K, Dalgleish AG, et al. (1988) Infection of B lymphocytes by the human immunodeficiency virus and their susceptibility to cytotoxic cells. Eur. J. Immunol. 18: 1315-1321.

45. Janssen O, Wesselborg S, Heckl-Ostreicher $\mathrm{B}$, et al. (1991) T cell receptor/CD3-signaling induces death by apoptosis in human $\mathrm{T}$ cell receptor $\gamma \delta^{+} \mathrm{T}$ cells. J. Immunol. 146: 35-39.

46. Kabelitz D, Pechhold K, Bender A, et al. (1991) Activation and activation-driven death of human $\gamma \delta \mathrm{T}$ cells. Immunol. Rev. 120: $71-88$.

47. Poccia F, Boullier S, Lecoeur H, Cochet $M$, Poquet Y, Colizzi V, Fournie J-J, Gougeon M-L. (1996) Peripheral V $\gamma 9 / V \delta 2$ T cell deletion and anergy to nonpeptidic mycobacterial antigens in asymptomatic HIV-1-infected persons. J. Immunol. 157: 449-461.

48. Wesch D, Kabelitz D, Friese K, Pechhold K. (1996) Mycobacteria-reactive $\gamma \delta \mathrm{T}$ cells in HIV-infected individuals: Lack of $\mathrm{V} \gamma 9$ cell responsiveness is due to deficiency of antigen-specific CD4 $\mathrm{T}$ helper type 1 cells. Eur. J. Immunol. 26: 557-562.

49. Gan Y-H, Pauza CD, Malkovsky M: (1995) $\gamma \delta \mathrm{T}$ cells in rhesus monkeys and their response to simian immunodeficiency virus (SIV) infection. Clin. Exp. Immunol. 102: 251255.

Communicated by B.R. Bloom. Accepted on September 24, 1996. 